\title{
Notes
}

\section{Toward Principles of Jury Equity}

The fairness of a system of laws may be evaluated by its ability to provide both justice and equity. Justice exists to the extent that persons conform their actions to the universally applied, general expectations of behavior promulgated by the legal system, while equity demands sufficient flexibility of application to permit these general expectations to adapt to the unique circumstances of individual cases. This tension between justice and equity as two aspects of a single legal system was discussed as early as Aristotle. ${ }^{1}$ And at least two crucial developments in the evolution of the English legal system-the use of king's courts before the middle of the thirteenth century, ${ }^{2}$ and of the

1. See ARIstotze, Nicomachean Ethics 141 (Bobbs-Merrill 1962):

What causes the problem is that the equitable is not just in the legal sense of "just" but as a corrective of what is legally just. The reason is that all law is universal, but there are some things about which it is not possible to speak correctly in universal terms. Now, in situations where it is necessary to speak in universal terms but impossible to do so correctly, the law takes the majority of cases, fully realizing in what respect it misses the mark. The law itself is none the less correct. For the mistake lies neither in the law nor in the lawgiver, but in the nature of the case.

See also Chroust, Aristotle's Conception of Equity, 18 Notre Dame Law. 119 (1942) Considerations of "equity," defined by Aristotle as justice in the individual case, would require the decisionmaker to depart from the general law in these special cases; $c f$. H. McClintock, Handoook of the Principles of Equity 1 (2d ed. 1948), which defines equity as "the" power to meet the moral standards of justice in a particular case by a tribunal having discretion to mitigate the rigidity of the application of strict rules of law so as to adapt the relief to the circumstances of the particular case."

2. Until England developed a nation-wide legal system at the end of the twelfth century, justice was administered by various local courts. W. WALsh, A TrEatise on EquiTY 2 (1930). These were the courts of the hundred and the shire during the Saxon period and the courts of the manor and the county in early Norman times. The king, however, as the source of all justice, could intervene as a matter of grace in any local case and remove the proceeding to the king's court or council. Id. at 1-2. See also H. McClintock, supra note 1, at 3-4. Thus, a dissatisfied local litigant who could persuade the king of the righteousness of his case had recourse to a settlement according to the king's conscience and reason. As a national court system was established under Henry II, the power to issue writs granting a litigant's request to have his case heard in the national or king's courts was delegated to the king's Chancellor. G. Bispham, ThE PRINciples of EQUiTY 6 (11th ed. 1931). These writs gradually became a matter of right rather than royal favor and the decisions of the king's courts marked the beginning of the common law. From the middle of the thirteenth century, however, these common law courts began to lose their discretionary powers and the types of writs which could be granted as well as the remedies available to the courts became institutionalized. By the middle of the fourteenth century, the concern for justice in the individual case which had given rise to the king's courts had been transformed into a rigid system of general law. See G. Bispham, supra at 6.8; H. McClintock, supra note 1 , at 4; W. WALSH, supra at 8. See also Adams, The Origin of English Equity, 16 CoLum. L. Rev. 87, 98 (1916); Barbour, Some Aspects of Fifteenth Century Chancery, 31 HARv. L. REv. 834, 859 (1918). 
Chancery in the fifteenth century ${ }^{3}$-centered on the struggle between general principles of law and individualized justice or equity.

In our present system, some argue that the jury's role is to adapt the general law to the circumstances of the particular case. ${ }^{4}$ Other commentators disagree, charging that a jury relies on unbridled prejudice and accidental feelings rather than on acceptable community notions of fairness. ${ }^{5}$ At stake are important questions of limiting or expanding the role of juries and of judges' instructions. Social psychological ${ }^{\circ}$ theory presents a model which helps put the debate in perspective ${ }^{7}$ and defines the empirical data needed for intelligent resolution of the issues.

3. As the common law courts became inadequate to meet the demands of special cases, for redress litigants once again petitioned the king as the source of justice. These petitions were referred to the Chancellor and came to be addressed directly to him. See G. Bisphas, supra note 2, at 7 ; H. McClintock, supra note 1, at 5; W. Walsh, supra note 2 , at 12,15 . The Chancellor's court during the fourteenth century ac= cepted only those petitions in which the remedy at common law was thought to be inadequate. F. Maitland, Equity 5-6 (2d ed. 1936). The Chancellor relied on his conscience, morality, and "natural justice" in fashioning relief, adapting his remedy to the special circumstances of each individual case. G. Bispham 9; H. McClintock 6; W. WALSF $18,25,41$.

Like the common law courts before them, the courts of Chancery, criticized for lack of predictability and abuse of discretion, felt pressures for institutionalization. By the eighteenth century it could be said that courts of Chancery or equity constituted a distinct legal system which emphasized general principles and exercised a substantive jurisdiction distinct from the common law courts. Although the principles and precedents of equity are often more adaptable to special cases than is the common law, see Lord Eldon's opinion in Gee v. Pritchard, 2 Swanst. 402, 36 Eng. Rep. 670 (1818), courts of Chancery or equity have lost much of their value as correctives of the general law in particular cases. See F. MaItLand, supra at 9-11; R. Newman, EQuiry and Law: A Comparative Study 9-13 (1961); W. Walsh 17, 41-43. See also Hohfeld, The Relations between Equity and Law, 11 Mich. L. REv. 537 (1923).

4. For example, Wigmore writes:

Law and Justice are from time to time inevitably in conflict. That is because law is a general rule (even the stated exceptions to the rules are general exceptions); while justice is the fairness of this precise case under all its circumstances ... Now this is where the jury comes in. The jury, in the privacy of its retirement, adjusts the general rule of law to the justice of the particular case .... It supplies that flexibility of legal rules which is essential to justice and popular contentment.

Wigmore, A Program for the Trial of Jury Trial, 12 J. AM. Jud. Soc'Y 166, 170 (1929).

5. See, e.g., J. Frank, Law and the Modern Mind 173-78 (1930); O. Holmes, The Common LAw 126 (1881).

6. "Social psychology" is that section of the disciplines of sociology and psychology concerned with the study of real or imagined personal relationships in a social context as they affect behavior and attitudes of the individuals involved. See Allport, The Historical Background of Modern Social Psychology, in 1 HANDBook of Social PsychologY 3 (G. Lindzey ed. 1954).

7. This inquiry is restricted to "internal" fairness, that is, to the handling of litigants once they have entered the system of justice. It does not deal with the external or society-wide effects of the legal system in promoting justice. For such an analysis from a social psychological perspective, see Macaulay \& Walster, Legal Structures and Restoring Equity, $27 \mathrm{~J}$. Soc. IssuEs 173 (1971). 


\section{The Debate Over Jury Sovereignty}

In 1670 Bushell's Case $^{8}$ established the right of a jury to find facts and apply the law to those facts according to its conscience without fear of judicial reprisal. In the United States, during the late eighteenth and early nineteenth centuries, the jury was legally empowered to decide both the facts and the law of a case in rendering its verdict. ${ }^{9}$ At the end of the nineteenth century, however, feelings about the sovereignty of the jury had changed. Fearful of the law becoming "as variable as the prejudices, the inclinations and the passions of men,"10 most jurisdictions significantly restricted the role of the jury, confining it to a determination of the facts alone. ${ }^{11}$ Today, the jury's proper role in rendering its verdict is to determine the facts of the case and to apply to those facts the law given it by the judge. ${ }^{12}$

In many cases, however, our legal system still gives the jury the right to render a general verdict, to determine the amount of damages, or to recommend sentence, and the jury, of course, may simply make a finding of facts in favor of the party which it feels should prevail. ${ }^{13}$

8. 6 How. St. Tr. $999(1670)$.

9. Howe, Juries as Judges of Criminal Law, 52 HARv. L. REv. 582 (1939). See, e.g., Georgia v. Brailsford, 3 U.S. (3 Dall.) I (1794); Dean of St. Asaph's Case, 21 How. St. Tr. 847 (K.B. 1783); remarks of Alexander Hamilton, quoted in J. AlEXANDER, A BRIEF Narration of the Case and Trial of John Peter Zenger 78 (1963).

In criminal trials this gave rise to the jury's right of nullification, which implies the right to set aside the instructions of the judge on the applicable law and to reach a verdict of acquittal based upon the jury's own conscience and sense of fairness. The right of nullification also implies the defendant's right to have the jury so instructed. See Scheflin, Jury Nullification: The Right to Say No, 45 S. CaL. L. REv. 168 (1972).

10. Sparf \& Hansen v. United States, 156 U.S. 51, 101 (1895), quoting G. WorrHINGTON, INQUIRY INTO THE POWER OF JURIES 193 (1825).

11. 156 U.S. at 101. See also United States v. Morris, 26 F. Cas. 1323 (No. 15,815) (C.C.D. Mass. 1851); United States v. Battiste, 24 F. Cas. 1042 (No. 14,545) (C.C.D. Mass. 1835); Springfield v. State, 96 Ala. 81, 11 So. 250 (1892); Commonwealth v. Parker, 10 Met. 263 (Mass. 1845).

The directed verdict, the special verdict, interrogation of juries, and the right of the judge to comment on the evidence were also developed in the nineteenth century as means of restricting the role of the jury. See Morgan, A Brief History of Special Verdicts and Special Interrogatories, 32 YALE L.J. 575 (1923); Note, The Changing Role of the Jury in the Nineteenth Century, 74 YALE L.J. 170, 183-89 (1964).

12. Indiana and Maryland, however, still recognize the right of jury nullification in criminal cases, Holliday v. State, 254 Ind. 85, 257 N.E.2d 679 (1970); Pritchard v. State, 248 Ind. 566, 230 N.E.2d 416 (1967); Giles v. State, 229 Md. 370,183 A.2d 359 (1962); Slansky v. State, 192 Md. 94, 63 A.2d 599 (1949), and Kansas is considering instructing its criminal juries accordingly. Scheflin, supra note 9 , at 205.07. In addition, the constitutions of 24 states recognize the jury's right of nullification in criminal or seditious libel cases. Id. at $204 \&$ n.130.

13. Several writers contend that the jury's role in today's legal system is just as powerful as it ever was, since its "power" to disregard the judge's instructions is tantamount to a "right" to disregard them. J. FrANk, supra note 5, at 83-84; cf. argument of Alexander Hamilton in People v. Croswell, 3 Johns. Cas. 337, 345 (N.Y. 1804). Some, in fact, maintain that our present system gives the jury more power than ever before, since the attention which is devoted to the propriety of the judge's legal instructions to the jury serves as a "great procedural opiate" by covering up 
In addition, the jury need not divulge the process by which it reached its decision nor must it explain or account in any way for its verdict to any authority. ${ }^{14}$ Thus the legal system gives to the jury the power, if not the right, in reaching its verdict to refuse to follow the substantive rules of law given it by the judge. ${ }^{15}$

The jury's sovereignty allows it to blunt the force of the general law when this is required for the equitable ${ }^{16}$ resolution of a special case. ${ }^{17}$ Legal commentators disagree, however, about the desirability of protecting the jury's power to disregard the judge's instructions and take into account "extra-legal" factors in reaching its verdict. This disagreement stems, in part, from conflicting views on how the jury exercises its power.

\section{A. Criticism of Jury Sovereignty}

Critics of jury sovereignty emphasize the unpredictability of jury discretion and stress the general incompetence and easy persuadability of juries. ${ }^{18}$ Judge Frank stressed the dysfunctional aspects of jury sovereignty. He maintained that legislatures and the judiciary have grown lax in revising outmoded rules because of their reliance on juries to make such legal revision on their own in the jury room. This leads, he observed, to an unfair lack of uniformity in decisions and to an unpredictability in the law, since such "jury law" will change from case to case and from jury to jury. ${ }^{19}$

appeals to the jurors' emotions and biases and hiding incompetent or malicious verdicts. See Skidmore v. Baltimore \& Ohio R.R., 167 F.2d 54, 61 \& n.25d (2d Cir. 1948). See also G. Clementson, Special Verdicts and Special Findings bY Juries 12 (1905); J. Frank 174; L. GREeN, JUDGE AND JURY 351 (1930). Kalven and Zeisel found that the juries they studied were often able to conduct their "revolt from the law within the etiquette of resolving issues of fact." $H$. Kalven \& $H$. Zeisel, The AMERICAN JURY I65 (1966); cf. Lord Devlin, who wryly noted, "I do not mean that they [the jury] often deliberately disregard the law. But if they think it is too stringent, they sometimes take a very merciful view of the facts." $p$. Devlin, THE ENFORCEMENT of Morals 21 (1959).

14. United State v. Dougherty, 473 F.2d 1113, 1132 (D.C. Cir. 1972); Bushell's Case, 6 How. St. Tr. 999 (1670).

15. United States v. Dougherty, 473 F.2d 1113 (D.C. Cir. 1972); Skidmore v. Baltimore \&: Ohio R.R., 167 F.2d 54, 57-58 (2d Cir. 1948). See also note 9 supra.

16. As used here, "equitable" means the conformity of particular decisions to the so-called natural sense of fairness of the ordinary man based on commonly shared moral principles. See ARIstotle, supra note 1, at 141-42; R. NEwMAN, supra note 3, at $13-14$.

17. See, e.g., note 4 supra. Several writers defend this role as the democratic analogue to appealing to the king's conscience from the local English courts and later from the common law courts, since in a democracy the "people," represented by the jury, are sovereign. See R. NewaAN, supra note 3, at 17; Scheflin, supra note 9, at 185-88.

18. See Hervey, The Jurors Look at Our Judges, 18 OkLA. STATE B.A.J. 1508 (1947); Hoffman \& Brodley, Jurors on Trial, 17 Mo. L. Rev. 235 (1952); Hunter, Law in the Jury Room, 2 Oho State L.J. 1 (1935).

19. J. FraNk, supra note 5, at 173-78; Skidmore v. Baltimore \& Ohio R.R., 167 F.2d at 54 n.14. 
Other critics allege that the jury for the most part does not understand the judge's instructions about the applicable law. ${ }^{20}$ Judge Frank ${ }^{21}$ argued that it is impossible to instruct 12 laymen in the intricacies of legal doctrine through instructions which are so finely complicated that many lawyers do not understand them. ${ }^{2 \cdot 2}$ Hunter ${ }^{23}$ and Hervey ${ }^{24}$ advanced evidence for this proposition in studies which found that persons directed to act as jurors in a simulated trial situation ("simulated jurors") often were not able to understand the legal instructions given them. In addition, in a post-trial survey of actual jurors, Hoffman and Brodley ${ }^{25}$ report that many jurors either did not understand or did not feel bound by the judge's instructions. ${ }^{26}$

Redmount argues that the jury's verdict can be treated solely as a product of persuasion. ${ }^{27} \mathrm{He}$ analyzes the trial as a process of persuasion and illustrates how fixed mental limits, emotional blocks, social biases, prior persuasion, internal dispositions, confusion, and ignorance serve as bases of juror decisionmaking. He feels that objective evidence pro-

20. See C. Bok, I, Too, Niconemus (1946); L. Green, supra note 13, at 351; Sunderland, Verdicts, General and Special, 29 YALE L.J. 253 (1920).

21. Skidmore v. Baltimore \& Ohio R.R., 167 F.2d at $60,64$.

22. The reader may wish to contemplate a "model" set of first degree murder instructions set forth in People v. Conley, 64 Cal. $2 \mathrm{~d} 310$ n.4, 411 P.2d 911 n.4, 49 Cal. Rptr. 815 n.4 (1966).

23. Hunter, supra note 18 .

24. Hervey, supra note 18 .

25. Hoffman \& Brodley, supra note 18. The early studies by Hunter, Hervey, and Hoffman and Brodley, however, are open to criticism because of their use of small samples and reliance on fairly crude methodology. For a more sophisticated empirical study which provides evidence that the jury is in fact satisfactorily competent, sec Kalven, The Dignity of the Civil Jury, 50 VA. L. REv. 1055, 1066-67 (1964).

26. An experiment reported by Broeder lends empirical support to the view that instructions to the jury can have an unexpected impact. Using the experimental juries of the Chicago Jury Project, he found that in civil cases where the simulated jury was told that the defendant did not have liability insurance, the average amount of damages awarded by the jury was $\$ 33,000$. Where the jury was told that the defendant did have insurance, the average award rose to $\$ 37,000$. But in cases where the jury learned that the defendant was insured but was instructed by the judge to disregard the defendant's insurance coverage, the average award again rose to $\$ 46,000$, higher than either of the other two conditions. Broeder, The University of Chicago Jury Project, 38 Neb. L. REv. 744, 753-55 (1959).

Besides the "common sense" explanation that the judgc's limiting instructions cxplicitly brought the defendant's insurance coverage to the jury's attention, the psychological theory of "reactance" offers an explanation for the result. Reactance theory maintains that men jealously guard their perceived freedom of action to such an extent that in many situations, when that freedom is threatened (for example, by the judge's instruction to disregard certain evidence), an individual will "react" to the perceived threat by reasserting his freedom so much the more forcefully in the threatened area. See J. Brem, A THEory of PsYchological ReActance (1966). If, in fact, this is what occurs in a trial setting, the implications for trial practice and for correction of objectionable statements made during the course of the trial are significant.

For support for the contrary view-that judges' instructions can have a strong influcnce on the jury's decisionmaking-see $\mathrm{pp}$. $1048-50$ \& note 49 infra.

27. Redmount, Persuasion, Rules of Evidence and the Process of Trial, 4 Loyous U.L. REv. 253 (1971). See also Commentary, Persuasion in the Courtroom, 10 DuQuesNe L. REv. 384 (1972). 
duced at the trial and legally relevant criteria given by the judge must compete disadvantageously with these other sources of persuasion in influencing the jury's verdict. Many legal treatises, written by litigators drawing on experiences in the courtroom, instruct lawyers how to select a jury which will be biased in their favor and how to exploit these legally irrelevant sources of persuasion. ${ }^{28}$

Critics of jury sovereignty argue that juries, rather than ensuring. the fair application of general law in particular cases, are led by bias, incompetence, and irrelevant persuasive factors to unpredictable and capricious decisionmaking. Their position is based on the positivist ${ }^{20}$ view that certainty and predictability are the hallmarks of a legal system and that, without legal guidelines, ordinary people would be influenced by current prejudice rather than commonly shared notions of natural justice or equity.

\section{B. Support for Jury Sovereignty}

Proponents of jury sovereignty, on the other hand, respect jury discretion as based on a moral sense of fairness which the jury shares with the larger community. Wigmore ${ }^{30}$ and Pound ${ }^{31}$ felt that "jury lawlessness" kept the law in tune with community values and allowed deviance when necessary from a general legal rule without entirely abandoning it. Kalven admires the "jury equity" uncovered by his empirical research ${ }^{32}$ and argues that jury reform of outmoded laws does not significantly impede legislative reform. ${ }^{33}$ Furthermore, cases

28. See H. Bodin, Selecting a Jury (1966); H. Gair, The Trial of a Negligence action (1953); I. Goldstein, Trial Technique (1935); R. Harris, Hints on Advocacy (18th ed. 1943); L. LAKE, How to WIN IN LAwsuits Before JURIES (1954); A. OsborN, The Mind of the Juror (1937); 2 L. Schwartz, Proof, Persuasion, and Cross Examination (1973). In addition, social scientists Jay Schulman and Richard Christie are currently using social psychological techniques with remarkable success in the selection of jurors on behalf of "political" defendants. TIME, Jan. 28, 1974, at 60 .

29. Bentham illustrates the position of positivist jurisprudence. He argues that without universal principles as a guide, people will make decisions on the basis of arbitrary sympathies and antipathies, whatever they happen to approve being called equitable and whatever they disapprove being called inequitable. Bentham views notions such as "common sense," "natural law," "natural justice," and "natural equity" as illusory inventions which rationalize arbitrary action and decisionmaking based on subjective biases rather than rational principles. J. BFNTHAM, AN INTRoDuction to THE Pringiples of Morals aNd Legislation 136-43 (1948). See also Note, supra note 11 , at 179 .

30. Wigmore, supra note 4.

31. Pound, Law in Books and Law in Action, 44 AM. L. Rev. 12 (1910).

32. Kalven, supra note 25, at 1075 .

33. Id. at 1071. Kalven contends that laws are rarely sound or unsound as a whole, requiring either application as is or outright legislative reform; the modifications which juries make are usually slight and often too stibtle to be codified. In addition, he notes that courts occasionally respond to persistent jury resistance by using that resistance as a reason for changing the law. Kalven, The Jury, the Law, and the Personal Injury Damage Award, 19 OHIo Srate L.J. 158 (1958). See, e.g., Vascoe v. 
such as Duncan v. Louisiana, ${ }^{34}$ Williams v. Florida, ${ }^{35}$ United States $v$. Spock, ${ }^{36}$ and most recently United States $v$. Dougherty ${ }^{37}$ indicate that the legal system itself acknowledges, with approval, that conscience or shared notions of equity, rather than bias, incompetence, or techniques of persuasion, are largely responsible for extra-legal jury decisions.

Writers such as Wigmore, Pound, and Kalven, in defending jury sovereignty, do not discuss the impact of general rules of law on the jury's sense of fairness. One might almost assume from their respective discussions that whenever the law in the slightest regard does not conform to the jury's sense of fairness in an individual case, the jury abandons the rule of law in favor of an equitable result. Sanford and Mortimer Kadish, ${ }^{38}$ however, argue that the jury gives a good deal of tolerance to laws which it believes are not fair in a particular case before implementing its own sense of justice. They maintain that the juror's role is so constructed that the rights and powers of the role may conflict with one another.

This tension between the jury's rights and its powers emphasizes the development of a significant justification for departures from general rules of law. The juror is told of his legal obligation to follow the judge's instructions, but the juror is also likely to be aware of his sovereignty and of the ultimate end of his role-justice in the individual case. ${ }^{39}$ When the juror perceives these two expectations as being in conflict (i.e., following the judge's instructions would not lead to an equitable result), he will still feel obliged to follow the judge's in-

Ford, 212 Miss. 370, 54 So. 2 d 541 (1951); cf. Furman v. Georgia, 408 U.S. 238 (1972). Kalven stresses the importance of jury equity in shaping the development of formal legal rules and notes that the jury's notion of equity is often the law in another jurisdiction or a reform proposal receiving consideration. Kalven, supra at 168 .

34. 391 U.S. 145 (1968). The Supreme Court stated that the jury's power to displace law by appeal to conscience was a fundamental characteristic of the American system of government. Id. at 156 .

35. 399 U.S. 78 (1970). Justice White wrote for the Court: "The essential feature of a jury obviously lies in the interposition between the accused and his accuser of the common-sense judgment of a group of laymen, and in the community participation and shared responsibility that results from that group's determination of guilt or innocence." Id. at 100 .

36. 416 F.2d 165 (1st Cir. 1969). The court found that "the jury, as the conscience of the community, must be permitted to look at more than logic" in reaching its verdict. $I d$. at 182 .

37. 473 F.2d 1113, 1138 (D.C. Cir. 1972). Chief Judge Bazelon, concurring in part and dissenting in part, argues that jury nullification "can and should serve an important function in the criminal process," $i d$. at 1141 , and that a defendant should have the right to have the jury told of its power of nullification. See also cases cited in note 12 supra.

38. Kadish \& Kadish, The Institutionalization of Conflict: Jury Acquittals, $27 \mathrm{~J}$. SOC. Issues 199 (1971).

39. See Judge Leventhal's opinion in United States v. Dougherty, 473 F.2d 1113, 1135 (D.C. Cir. 1972). 
structions unless the justification for disregarding those instructions is sufficiently compelling to permit the juror to follow his own notions of justice. Thus, the juror is expected to tolerate perceived inequity in the application of general rules of law to the point where he feels that the resulting inequity would be so great and so certain that his departure from the general law is justified. ${ }^{40}$ This narrow right of the jury is termed "legitimated interposition," and it is far different from a right to disregard the law whenever the result of applying the law seems inequitable.

The strongest empirical support for the proponents of the jury's sense of justice, and in turn of jury sovereignty, comes from the most thorough empirical study of the American jury to date, the Chicago Jury Project. Kalven and Zeisel ${ }^{ \pm 1}$ collected judges' opinions of jury performance in over 3,500 actual trials. The differences in outcomes between judge and jury were small and suggested that the jury substantially agrees with the law's prescriptive norms. There were, however, several consistent differences. The jury interpreted the law of self-defense more liberally than did the judge; ${ }^{42}$ it was inclined to evaluate the "contributory fault" of a victim in criminal cases; ${ }^{43}$ it was reluctant to penalize what it felt were trivial offenses; ${ }^{44}$ it hesitated to enforce laws against so-called "crimes without victims" such as poaching, public intoxication, gambling, and drunken driving,; ${ }^{45}$ it was often sympathetic to the defendant who was intoxicated at the time of his alleged offense; ${ }^{46}$ and in reaching its verdict it took account of any coincidental suffering the defendant may have incurred during or as a result of the crime. ${ }^{47}$ Kalven and Zeisel conclude that, although on the whole the jury's "revolt" from the law is a minor one, the jury consistently resists applying the substantive law in several areas, generally because the laws are considered unfair or fail to make distinctions deemed important by the jury..$^{48}$ It is the consistency with which juries were found to deviate from the law in certain areas that is important,

40. This notion of the juror's role builds into the system a tolerance for laws which are just in most cases or which are only mildly unjust. Such tolerance is very close to that put forward by Rawls in his explanation of an individual's duty to comply with what he perceives to be an unjust law. See J. Rawls, A THEORY of JUSTICE 333-91 (1971).

41. H. KALVEN \& H. ZEISEL, supra note 13.

42. Id. at 229-31.

43. Id. at $243,257$.

44. Id. at 258-59.

45. Id. at 296-97.

46. Id. at $334-38$.

47. Id. at 301-05.

48. Id. at 286, 493-95. 
since this suggests the influence of relatively stable notions of jury equity. 40

The key to the position of proponents of jury sovereignty is the argument that jurors, in departing from general law, rely on a shared ${ }^{50}$. sense of justice which is accessible to the ordinary person..$^{51}$ If this individual sense of equity in fact exists and is shared in roughly the same form by members of a local community, then the fear of Judge Frank and others ${ }^{52}$ that the jury's sovereignty leads to incompetence and unbridled discretion in decisionmaking should be greatly alleviated.

In sum, the occasionally conflicting expectations that our system of justice act according to universal laws and yet bring about justice in

49. Another researcher involved with the Chicago Jury Project obtained evidence of an additional dimension of jury equity. Using experimental techniques, Simon had a set of subjects listen to tape-recorded, simulated trials, following procedures which resembled as closely as possible those of an actual trial. She found that juries given the "M'Naghten instruction," M'Naghten's Case, $10 \mathrm{CI}$. \& F. 200, 8 Eng. Rep. 718 (H.L. 1843), on insanity were significantly less likely to acquit by reason of insanity than those subjects given the "Durham instruction," Durham v. United States, 214 F.2d 862 (D.C. Cir. 1954). A third group of subjects who were given no instructions at all responded almost identically to the group given the Durham instructions. Simon therefore concludes that the Durham rule on insanity reflected her subjects" "natural sense of equity" much more than did the M'Naghten rule. R. Simon, ThE JuRY AND THE DEFENSE OF INSANITY 216 (1967).

50. The juror's sense of justice is "shared" with other members of society to the extent that it is a product of fairly stable socialization experiences common to society and reflccts basic societal values about what is just. See, e.g., Aronfreed, The Socialization of Altruistic and Sympathetic Behavior: Some Theoretical and Experimental Analyses, in Altruism and Helring Behavior 103 (J. Macaulay \& L. Berkowitz eds. 1970). Ideally, therefore, 12 jurors will not have 12 different notions about what is an equitable result. In a pluralistic society such as our own, however, individuals are socialized into many different sub-groups, and thus a 12-person jury may bring several different senses of equity into the courtroom. The extent of such differences, with their implications for the selection of a jury which is representative of the make-up of the community at large, remains a question for future research. See also note 105 infra.

51. Several jurisprudential writers support the existence of commonly held notions of justice, an idea generally associated with the jurisprudence of natural law. See H. Spencer, Justice: BeiNg Part IV of the Prisciples of Ethics 29-34 (1891); N. TIMAShefF, AN INTRODUction to THE Sociology of LAw 71-72, 75 (1939); Note, supra note 11, at 178. Timasheff reasons that a situation is just to the extent that it is a concrete embodiment of a recognized system of values. Where the relevant system of values is not determined by society but is individual instead, no outside observer is able to judge how just a situation may be. Socially recognized systems of values exist, however, and to the extent that such value systems are shared by members of society, outside observers of an event may validly decide to what extent the event conforms to the social system of values. Generally, agencies such as courts evaluate given situations, but a member of society who shares in its system of values, for instance a juror, may also make this evaluation. Timasheff maintains, then, that a socialized member of a group will have a sense of what his group defines as equitable. N. TIMASHEFF, supra at 75 .

Spencer explains that an "altruistic sentiment of justice" develops in the individual in the course of his adaptation to social life. Because of his intelligence and his dependence on a group, man develops a capacity to sympathize with other men. A feeling displayed by one man is apt to arouse kindred feelings in others. As a result of this ability to imagine himself in the place of another, altruistic sentiments of justice are formed and shared with other members of society. H. SPENCER, supra.

52. See \$ I.A supra. 
the individual case are reflected in the role of the jury. The jury is legally expected to follow the judge's instructions in rendering its verdict, but practically it has the power to deviate from the general law. The crucial element in the disagreement between those legal commentators who support and those who criticize the jury's sovereignty is the degree to which juries are thought to rely on commonly held notions of justice or equity in refusing to apply the general law. Although it is an important element in the controversy over the proper function of the jury in our system of justice, the jury's sense of equity remains relatively poorly understood.53

\section{Social Psychology and Shared Notions of Equity}

In recent years social psychologists have begun to construct experimental models of the judicial system to discover what extra-legal devices individuals use in making judgments of blameworthiness. ${ }^{54}$ Such research has been done to a large degree by investigators testing a major theoretical orientation of social psychology termed "equity theory."

\section{A. Postulates of Equity Theory}

Equity theory is developed in the work of Homans ${ }^{5 \bar{J}}$ and $\mathrm{J}$. Stacy Adams, ${ }^{56}$ and it has recently been reviewed by Walster. ${ }^{57}$ It presumes man to be an economic, self-interested actor who, however, has been socialized and is a member of a social group. Equity theory postulates that, although individuals will try to maximize their individual outcomes (i.e., increase their rewards and minimize their costs), ${ }^{58}$ unrestrained efforts at self-aggrandizement would lead to social conflict which would eventually lower everyone's outcomes. Since groups can maximize collective outcomes by evolving accepted systems for apportioning rewards and costs among members, they will evolve such sys-

53. For example, to what extent is it the juror's sense of equity rather than his incompetence or prejudices which accounts for the jury's deviation from the law? What effect do the judge's instructions have on the juror's exercise of his sense of equity? What are the dimensions, the relevant considerations, of the juror's sense of equity and to what extent do they differ from legally relevant criteria?

54. This focus is reflected by the latest American Psychological Association Convention, Montreal, August 1973, which sponsored a symposium on "Social Psychology and the Courtroom." In addition, the most recent American Sociological Association Convention, New York, August 27-30, 1973, restricted the scope of the section on social psychology to studies involving the jury.

55. G. Homans, Social Behavior: Its Elementary Forms (1961).

56. Adams. Inequity in Social Exchange, in 2 Advances in Experimental Social Psychology 267 (L. Berkowitz ed. 1965).

57. Walster, Berscheid \& Walster, New Directions in Equity Research, $25 \mathrm{~J}$. PERs. \& Soc. PsYch. 151 (1973).

58. Id. The meaning of "rewards" and "costs" is discussed at pp. 1033-34 infra. 
tems and will attempt to induce members to accept and adhere to them. ${ }^{50}$ The accepted systems which evolve for apportioning rewards and costs, then, become the criteria for "equitable" behavior. Thus, in any society there will be a general consensus as to what constitutes an "equitable relationship."60

Although every society will institutionalize systems for equitably apportioning rewards and costs, the perception of what constitutes an equitable apportionment may vary from culture to culture. In spite of this variance, equity theory posits a single general principle which expresses the diverse conceptions about what is equitable. This principle states that an equitable relationship exists when the person evaluating the relationship (who could be either a participant in the relationship or an outside observer) perceives that each participant is receiving equal proportional outcomes from the relationship (i.e., the ratios of the participants' outcomes to inputs are equal). ${ }^{61}$

Adams $^{62}$ expressed this principle in the form of an equation:

$$
\frac{\text { Outcomes }_{\mathrm{A}} \text { (rewards-costs) }}{\text { Inputs }_{\mathrm{A}} \text { (assets-liabilities) }}=\frac{\text { Outcomes }_{\mathrm{B}} \text { (rewards-costs) }}{\text { Inputs }_{\mathfrak{B}} \text { (assets-liabilities) }}
$$

"Outcomes" are the positive ("rewards") and negative ("costs") consequences that a participant in a relationship incurs from his relationship with another. Generally "inputs" are the participant's contributions to the relationship which entitle him to rewards or costs. "Assets" are positive inputs which entitle the participant to rewards; "liabilities" are negative inputs which entitle him to costs. In social settings, for example, assets may consist of work done, physical attractiveness, or social status, while laziness, nonconformity, or failure may constitute liabilities. ${ }^{63}$ For example, in the employer-employee relationship, higher wages (increased outcome) should lead the employee to work harder (increased input) to "justify" the pay raise (to keep his ratio of out-

59. Walster, Berscheid \& Walster, supra note 57, at 151 .

60. Id. at 153 .

61. Id. at 152 .

62. Adams, supra note 56 .

63. The merit and strength of relevant "outcomes" and "inputs" in the equity equation are nevertheless probably perceived rather differently by two participants in a relationship, each distorting his perception to justify larger personal outcomes. Also, the victim in an inequitable relationship is likely to feel more distress than the harmdoer. Legant, Equity Theory and the Law: Suggestions for Future Research 12 (paper presented at the American Psychological Association Convention, August 1973). An observer's perception of the relevant inputs and outcomes of participants in a relationship is likely to undergo similar distortion to the extent that he identifies with either of the participants. $I d$. This supports the view of trial tacticians that attorneys should select jurors who are similar to his client and thus more likely to identify with him. See H. Bodis, supra note 28. 
comes to inputs equal to that of his employer). By the same process, an increase in profits (increased outcome) for the employer, who has not increased his own capital or work input, will increase the employer's ratio of outcomes to inputs and should motivate the employee either to seek higher wages or to reduce his own work input. ${ }^{\text {g. }}$

Although society attempts to reward equitable behavior and to increase the costs for inequitable behavior, an individual will still behave inequitably as long as he perceives that he can maximize his total outcomes by so doing. Because individuals are socialized and conditioned to behave equitably, however, equity theory maintains that when individuals find themselves participating in inequitable relationships, they become "distressed"; the more inequitable the relationship, the more distress individuals feel. ${ }^{05}$ The distress of those who are receiving less than they perceive to be equitable may take the form of anger, ${ }^{60}$ while those who are receiving more than they perceive they deserve also experience distress, generally in the form of guilt. ${ }^{67}$

The final postulate of equity theory is that individuals who discover that they are in an inequitable relationship will attempt to eliminate their distress by restoring equity. ${ }^{68}$ The greater the inequity that exists, the more distress individuals feel, and the more motivated they are to restore equity. Equity may be restored in either of two ways. First, the individual may restore "actual equity" by appropriately altering his own outcomes or inputs or the outcomes or inputs of the other participant in the inequitable relationship. ${ }^{69}$ Secondly, the indi-

64. See, e.g., Adams \& Rosenbaum, The Relationship of Worker Productivity to Cognitive Dissonance about Wage Inequities, 46 J. Arplied PsYch. 161 (1962).

65. Walster, Berscheid \&. Walster, supra note 57, at 153.

66. See E. Jaceues, Equitable PaymeNT (1961); Leventhal, Allen \& Kemelgor, Reducing Inequity by Reallocating Rewards, 14 PsYCHONomic ScIENCE 295 (1969); Thibaut, An Experimental Study of the Cohesiveness of Underprivileged Groups, 3 HuMAN REL. 251 (1950); Walster, Berscheid \& Walster, Reactions of an Exploiter to the Exploited: Compensation, Justification or Self-Punishment?, in ALTRUISM AND HELPING BEHAvior, supra note 50 , at 179 .

67. See E. JACQUEs, supra note 66: Adams \& Rosenbaum, supra note 64: Adams, Toward an Understanding of Inequity, $67 \mathrm{~J}$. ABNormaL \& Soc. Psxch. 422 (1963); Leventhal, Allen \& Kemelgor, supra note 66.

68. Walster, Berscheid \& Walster, supra note 57, at 153-54.

69. For example, Leventhal, Allen \& Kemelgor had experimental subjects work on arithmetical tasks together with a confederate of the experimenters. After the set of tasks was completed, the subject and confederate were given $S 1.40$ to be divided between them. The confederate made the initial division, systematically allocating more than half the reward to some subjects and less than half to others, even though both the subject and confederate had worked equally hard to earn the reward. After this initial division the subjects were permitted to alter slightly the initial allocation of the reward. The results showed that those subjects initially given more than half the reward decreased their share, while the subjects initially given less than half increased their share of the reward when given the chance to do so. Leventhal. Allen \&. Kemelgor, supra note 66. See also Leventhal \& Anderson, Self-Interest and the 
vidual may restore "psychological equity" to what he perceives to be an inequitable relationship by changing his perception of his own or the other's outcomes and inputs. ${ }^{70}$ One major question still unanswered by equity theorists and researchers is under what conditions individuals will choose to restore actual equity rather than merely psychological equity-two radically different approaches to resolving the imbalance. ${ }^{71}$

\section{B. Observers' Motivation to Restore Equity}

A positive finding by equity researchers, however, is that both participants and observers of a relationship are equipped to assess its equitable balance through socialized norms of equity. Equally important, there is evidence that observers of an inequitable relationship also experience distress in much the same way as do participants in the relationship and are thereby similarly motivated to restore actual or psychological equity to the perceived inequitable relationship. $^{22}$

Maintenance of Equily, $15 \mathrm{~J}$. PrRs. \& Soc. PsYch. 57 (1970); Leventhal \& Lane, Sex, Age and Equily Behavior, 15 J. PERs. \& Soc. PsYch. 312 (1970); Leventhal \& Michacls, Extending the Equily Model: Perception of Inputs and Allocation of Reward as a Function of Duration and Quantity of Performance, 12 J. Pers. \& Soc. Psych. 303 (1969).

There is evidence that a principle of utility may alter strict compliance with the equity equation: Rewards may tend to be given to those who can make the best use of them. Leventhal and his associates have found experimental evidence of the "conservation of reward value." Leventhal, Weiss \& Buttrock, Attribution of Value, Equity, and the Prevention of Waste in Reward Allocation, 27 J. PERs. \& Soc. PSYCH. 276 (1973). They found that subjects gave relatively more reward to recipients most likely to make use of it, especially where the reward would deteriorate if not used promptly and where recipients had made good use of similar rewards on past occasions. This equity principle of conservation of reward is reflected in the legal principle that damages for breach of contract should be the cost of performance of the contract only where this "does not involve unreasonable economic waste." Peevyhouse v. Garland Coal \& Ifining Co., 382 P.2d 109, 112 (Okla. 1962).

70. For example, in the experiment by Leventhal, Allen \& Kemelgor, supra note 66, discussed at note 69 supra, subjects were allowed to redistribute only $\$ .05$ of the total reward, and therefore actual equity was probably not fully restored for most subjects. Through a questionnaire administered at the end of the experiment, the experimenters were able to measure certain perceptual distortions by the subjects. "The responses of the subjects indicated that the greater the negative inequity imposed by the confederate in his initial division of the reward, the greater was the confederate's perceived control over the division of the reward and the greater was the subject's intention of taking a larger share of the reward in future tasks. See also Lerner, Observer's Evaluation of a Victim: Justice, Guilt, and Veridical Perception, $20 \mathrm{~J}$. PERs. \& Soc. PSYCH. 127 (1971); Lemer \& Lichtman, Effects of Perceived Norms on Altitudes and Altruistic Behavior Toward a Dependent Other, 9 J. PERs. \& Soc. IsYch. 226 (1968); Lerner \& Matthews, Reactions to Suffering of Others under Conditions of Indirect Responsibility, 5 J. PERs. \& Soc. Psych. 319 (1967); Lerner \& Simmons, Observer's Reaction to the "Innocent Victim": Compassion or Rejection?, 4 J. Pers. \& Soc. Psych. 203 (1966); Simmons \& Lerner, Altruism as a Search for Justice, 9 J. Pers. \& Soc. Psych. 216 (1968).

71. See Macaulay \& Walster, supra note 7. A harmcloer is probably more disposed to restore psychological equity than is his victim, who would want actual equity restoration in the form of compensation.

72. See Legant, supra note 60 , at 3 . 
Equity-restoring behavior on the part of observers of inequitable relationships has been studied experimentally by Lerner and his associates. ${ }^{73}$ Lerner contends that all people have a need to believe in a world ordered by justice, ${ }^{74}$ i.e., that the world is not governed by a series of random reinforcements but rather that "there is an appropriate fit between what they do and what happens to them-their outcomes." 75 This need to believe in a just world is threatened for an observer of inequity. The observer, therefore, will be motivated to restore either actual or psychological equity to the perceived inequitable relationship in order to maintain his belief in a just world. Where the observer has no power to change the perceived inequity, he may restore psychological equity by "blaming the victim" "is for the inequity, but when given a chance to restore actual equity to the relationship, the observer will attempt to do so. ${ }^{77}$

This finding-that observers of inequitable relationships are themselves motivated to restore equity to the observed relationship-could have extremely important implications for the legal debate over the degree to which juries are guided by learned notions of justice rather than accidental feelings when they deviate from the general law. The juror, of course, is an excellent example of an observer of alleged inequitable relationships who has the capacity to restore actual as well as psychological equity. It appears that the juror, therefore, has a real, personal need to restore equity to inequitable relationships between plaintiffs and defendants, relying on his sense of what constitutes an equitable relationship which he shares with other members of society. The "equity equation," 78 therefore, might be able to serve as a model of the little understood notion of the juror's sense of equity. As con-

73. See articles cited in note 70 supra.

74. Lerner \& Simmons, supra note 70, at 203.

75. Id.

76. See generally W. RYan, BLaming the Victim (1971).

77. The tendency of observers to restore actual rather than merely psychological equity when given the opportunity to do so was demonstrated experimentally by Lerner and Simmons. The subjects believed that they were watching the "victim" in a learning exercise who was given an electric shock whenever she made a mistake. After 10 minutes of such observation, half the subjects were told that they could vote for the victim to undergo a positive reinforcement schedule next or to continue in the negative "shock" condition. Then all the subjects were asked to evaluate the victim. Subjects who were not given the opportunity to change the victim's fate derogated her and found her relatively unattractive (restoring equity psychologically). The other subjects all voted (except for one) to assign her to the positive reward condition, thus ameliorating her fate and restoring actual equity. Lerner \& Simmons, supra note 70. An observer may, in fact, be more motivated to restore actual equity than the harmdoing participant, since the observer need not distort his perception of the relationship (thereby restoring psychological equity) in order to avoid distress and actual equity restoration.

78. See note 61 supra. 
tinued research sketches in the dimensions of the rewards, costs, assets, and liabilities which constitute an equitable relationship in our society, our questions about jury equity may come to be answered. ${ }^{79}$

One difficulty with equity theory is that it provides little theoretical guidance for discovering what constitute the relevant outcomes and inputs of an equitable relationship. Determining the relative weights which individuals attach to various outcomes may not be terribly difficult, but discovering what the inputs (both assets and liabilities) are which entitle participants in a relationship to rewards and costs and, furthermore, how the existence of these inputs are inferred by the observer (juror) of a relationship, is much more complex. This task is essential, however, in discovering the "principles" of jury equity.

\section{Attribution Theory: Refining the Equity Equation}

Social psychologists who have made contributions toward determining the relevant assets and liabilities of the equity equation have generally been concerned with the process by which observers come to attribute responsibility or blameworthiness to an actor for a given event. Heider ${ }^{80}$ and Thibaut and Reicken ${ }^{81}$ contend that people have a need for perceptual order and that the attribution of internal dispositions (which may also be inputs in the equity equation) to others is an important source of this order, allowing people to maintain stable cognitions about the meaning of various behaviors. For example, assume that an observer witnesses a man strike a small child. Without more information, the observer will tend to justify ${ }^{82}$ the action by inferring that the child deserved the blow or that the man, perhaps the

79. For example, experimental research by Jones \& Nisbett, The Actor and the Observer: Divergent Perceptions of the Causes of Behavior, in ATtRIBution: Perceiving THE Causes of Behavior 79 (1972); Nisbett, Caputo, Legant \& Marecek, Behavior as Seen by the Actor and as Seen by the Observer, 27 J. PERs. \& Soc. Psych. 154 (1973); Storms, Videotape and the Attribution Process: Reversing Actors' and Observers' Point of View, $27 \mathrm{~J}$. Pers. \& Soc. Psych. 165 (I973), indicates that an actor feels that his behavior is caused by external factors in his environment, whereas an observer of the actor's behavior feels that the behavior is caused by characteristics of the actor. Legant, supra note 60 , at 12 , reasons that due to this fundamental difference in perception, "a defendant may tend to offer situational explanations for his behavior, such as financial need, social pressure, or road conditions, while a victim, plaintiff, witness, judge, juror, or member of the public will tend to stress reasons involving moral character and intent. In fact, the law, as observer, refuses to consider extenuating situational circumstances such as prior misfortunes in adjudicating guilt." Thus, in those situations in which a juror is likely to identify with a defendant, the juror also will tend to attribute the defendant's behavior to environmental factors and therefore in these situations the juror's sense of equity might diverge from the applicable law.

80. Heider, Social Perception and Phenomenal Causality, 51 Psych. Rev. 358 (1944).

81. Thibaut \& Reicken, Some Determinants and Consequences of the Perception of Social Causality, 24 J. Pers. 113 (1955).

82. See the discussion on need to believe in a just world at pp. 1035-36 supra. 
child's father, is punishing it with no intention of doing the child any harm. Told, however, that the man is generally cruel, the observer will tend to infer that the child is generally well-behaved, the man intended to strike the child, the act is inequitable, and the man should be held responsible for his inequitable action.

Heider divides perception of causality into "personal causation," which includes events which another produced and intended to produce, and "impersonal causation," which encompasses externally caused events and those caused by an actor who did not intend to cause them. ${ }^{83}$ Heider then contends that people hold others responsible only for events which result from personal causation. Relying on Piaget's work on the development of perceptions of causality in children, ${ }^{84}$ Heider proposes that all people go through five stages in the development of their perception of responsibility for an event. ${ }^{85}$ At the first stage, we perceive another person as responsible for events in any way connected with him. At the second stage, responsibility for an event is attributed only if the other has actually caused the event. At the third stage, forseeability of the consequences of the other's act as well as causality is required before responsibility will be attributed to the other. At the fourth stage, the other is held responsible only for events and consequences which he intended to produce. ${ }^{80}$ Finally, Heider describes a fifth stage of the development of notions of responsibility in which the other is not held entirely responsible even for acts and consequences which he intended to produce. In this stage, various justifications and excuses ${ }^{87}$ lead the observer to sympathize with the other

83. F. Heider, The Psychology of Interpersonal Relations $100-09$ (1958).

84. J. Piaget, The Moral Judgment of the Child (1932).

85. F. HeInER, supra note 83, at 112-14.

86. Studies by Garrett \& Libby, Role of Intentionality in Mediating Responses 10 Inequity in the Dyad, $28 \mathrm{~J}$. Pers. \&. Soc. Psycir. 21 (1973); Greenberg \& Frisch, Effects of Intentionality on Willingness to Reciprocate a Favor, 8 J. ExP. Soc. Psrch. 99 (1972); and Rule \& Duker, Effects of Intentions and Consequences on Children's Evaluations of Aggressors, 27 J. PERs. \& Soc. PsYch. 184 (1973), provide experimental evidence of the powerful effect of intent as a negative input. See also Maselli \& Altrocchi, Attribution of Intent, 71 PsYch. Bull. 445 (1969); and Walster, Berscheid \& Walster, stupra note 57, at 167-68, for a review of studies which focus upon the importance of intent in attribution of responsibility. As Walster concludes: "When the inequity is intentionally produced, participants in an inequitable relationship will experience more distress and will have stronger desires to restore equity to the relationship than if the inequity occurs inadvertently." Id. at 167 .

87. The relationship of excuses and justifications is illustrated in the related theoretical works of Scott \& Lyman, Accounts, 33 AM. Soc. Rev. 46 (1968), who discuss the nature of "accounting" to others for one's apparent improprieties, and Sylies \& Matza, Techniques of Neutralization, 22 AM. Soc. REv. 664 (1957), who discuss techniques for rationalizing one's improper actions to oneself. According to their analyses, an "excuse" is a direct denial of having caused, having forseen the consequences of, or having intended to commit the act of which one is accused. Such an excuse attempts to deny responsibility for an event by negating the crucial elements of Heider's Stages 
and refrain from holding him responsible for the intended event. ${ }^{8 s}$

The variables in Heider's fifth stage which diminish the attribution of responsibility for an intentional act can be viewed as positive inputs in the equity equation's model of jury equity, entitling a participant in a relationship to more rewards and fewer costs. Clarification of these variables through further research should therefore illuminate the dimensions of the juror's sense of equity. Comparisons could then be made between the juror's sense of equity and various legal criteria of responsibility and exculpation, such as mens rea ${ }^{89}$ provocation, ${ }^{90}$ selfdefense, ${ }^{01}$ duress, ${ }^{92}$ necessity, ${ }^{93}$ intoxication, ${ }^{94}$ diminished capacity ${ }^{95}$

"rwo, Three, or Four, respectively. An alternative to the excuse is the "justification," whereby one concedes responsibility for the consequences of an event but denies that the event was in fact inequitable. Contentions that "nobody got hurt," "he deserved it," or "everybody does it" are common justifications.

88. Experimental support for Heider's conception of developmental stages in the attribution of responsibility is provided in studies by Shaw \& Sulzer, $A n$ Empirical Test of Heider's Levels in Attribution of Responsibility, $69 \mathrm{~J}$. ABNormal \& Soc. Psych. 39 (1964); Shaw, Some Cultural Differences in Sanctioning Behavior, 8 Psychonomic SCIENCE 45 (1967); and Sulzer \& Burglass, Responsibility Attribution, Empathy, and Punitiveness, $36 \mathrm{~J}$. Pers. 272 (1968). In these studies subjects were presented with 20 stories, four of the stories presenting the minimum factors required for attribution of responsibility at each of Heider's five stages. Subjects were asked how responsible the central actor in each story was for the negative or positive consequences of an event. In general, subjects attributed more responsibility to the central actor as the stories moved from Stage One (association) to Stage Four (intentional causation) and somewhat less responsibility in Stage Five (extenuating circumstances). There was an extremely high rate of disagreement among subjects, however, in attributing responsibility at Stage Five. By further investigating the variables which affect responsibility attribution in light of various extenuating circumstances, researchers can clarify those mitigating factors which are relevant inputs in the observer's sense of equity.

89. See Model Penal Code $\$ 2.02$ (Proposed Official Draft 1962) and Comment at 123-32 (Tent. Draft No. 4, 1955); Regina v. Cunningham, 41 Crim. App. R. 155, 3 Weekly L.R. 76 (1957); People v. Wolff, 61 Cal. 2d 795, 394 P.2d 959, 40 Cal. Rptr. 271 (1964).

90. See Model Penal Code $\$ 210.3$ (Proposed Official Draft 1962) and Comment at 40.48 (Tent. Draft No. 9, 1959); Maher v. People, 10 Mich. 212, 221-22, 81 Am. Dec. 781, 786 (1862); Haley v. State, 123 Miss. 87.85 So. 129 (1920); State v. Bongard, 330 Mo, 805, 51 S.W.2d 84 (1932); Elsmore v. State, 132 Tex. Ct. App. 261, 104 S.W.2d 493 (1937).

91. See Model Penal Code $\$ 3.04(1)$ (Proposed Official Draft 1962) and Comment at 14.30 (Tent. Draft No. 8, 1958); Springfield v. State, 96 Ala. 81, 11 So. 250 (1892); State v. Mayberry, 360 Mo. 35, 226 S.W.2d 725 (1950); State v. Abbott, 36 N.J. 63, 174 A.2d 881 (1961).

92. See Moder. Penal Code $\$ 2.09$ (Proposed Official Draft 1962) and Comment at 2-16 (Tent. Draft No. 10, 1960); D'Aquino v. United States, 192 F.2d 338, 358 (9th Cir. 195I); Annot., 40 A.L.R.2d 908 (1955)

93. See Model PenAL CodE $\$ 3.02$ (Proposed Official Draft 1962) and Comment at 5-10 (Tent. Draft No. 8, 1958); United States v. Holmes, 26 Fed. Cas. 360 (C.C.E.D. Pa. 1842); Comment, The Law of Necessity as Applied in the Bisbee Deportation Case, 3 ARIZ. L. Rev. 264 (1961); Annot., 93 A.L.R.2d 1366 (1964).

94. See MODEL Penal Cone $\$ 2.08$ (Proposed Official Draft 1962) and Comment at $2-13$ (Tent. Draft No. 9, 1959); People v. Conley, 64 Cal. 2d 310, 411 P.2d 911, 49 Cal. Rptr. 815 (1966); Roberts v. People, 19 Mich. 401 (1870). But see State v. Shipman, 354 Mo. 265, 189 S.W.2d 273 (1945).

95. See Model PenAl CODE $\S 4.02$ (l'roposed Official Draft 1962) and Comment at 193 (Tent. Draft No. 4, 1955); People v. Conley. 64 Cal. 2d 310, 316, 411 P.2d 911, 914, 49 Cal. Rptr. 815, 818 (1966); People v. Wolff, 61 Cal. 2d 795, 394 P.2d 959, 40 Cal. Rptr. 271 (1964); People v. Gorshen, 51 Cal. 2d 716, 336 P.2d 492 (1959). 
insanity, ${ }^{96}$ and the aggravating and mitigating circumstances in the Model Penal Code ${ }^{97}$ and proposed Federal Criminal Code ${ }^{98}$ concerning capital punishment.

The law in fact seems to reflect closely Heider's levels of responsibility in the amount of blameworthiness it allocates to specific acts. No legal responsibility is attached at Stage One, mere association. There are but a few instances of "strict liability" which require only causttion (Stage Two) by the harmdoer for the legal system to intervene. Tort liability, however, generally requires that the resulting harm have been reasonably foreseeable (Stage Three) by the harmdoer. Finally, criminal laws generally require that the harmdoer have intended (Stage Four) to commit the criminal act. In addition, some justifications (Stage Five) such as self-defense, provocation, or duress are legally recognized as defenses to a criminal prosecution. ${ }^{99}$ Therefore, one would expect the jury's criteria for determining responsibility for a given inequitable act not to vary significantly from the legal criteria. ${ }^{100}$

Specific internal states, such as intentionality, are certainly important determinants of the amount of responsibility an observer will attribute to an actor. Such internal states, whether they are legally part of the mens rea of an offense or simply constitute part of the observer's sense of equity, must usually be imputed to the actor, since they are not externally observable. ${ }^{101}$ The process by which internal states are so inferred thus becomes important in gaining a deeper understanding of the jury's sense of equity. Jones and Davis suggest a model of the process by which people infer an actor's specific internal state from observable events. ${ }^{102}$ They contend, like Heider, that the observer needs to and does account for the causes of behavior, and that one way he does so is in terms of the effects of that behavior. Also, behavior is accounted for to the extent that an observer can associate it with a general internal disposition of the actor. For example, an observer can account for the man striking a child (the observable event) by inferring

96. See Model Penal Cone $\$ 4.01$ (Proposed Official Draft 1962) and Comment at 156-60 (Tent. Draft No. 4, 1955); M'Naghten's Case, $10 \mathrm{Cl}$. \& F. 200, 8 Eng. Rep. 718 (H.L. 1843); United States v. Brauner, 471 F.2d 969 (D.C. Cir. 1972); Durham v. United States, 214 F.2d 862, 874-75 (D.C. Cir. 1954).

97. See Model Penal Cone $\$ 210.6$ (Proposed Official Draft 1962) and Comment at $63-80$ (Tent. Draft No. 9, 1959).

98. Proposed Federal Criminal Code, Provisional $\$ 3604$ (Final Report, National Commission on Reform of Federal Criminal Laws, 1971).

99. See pp. 103940 supra.

100. H. Kalven \& H. ZeIsel, supra note 13 , at 193-347, in fact indicate that this is probably the case.

101. The possible difficulty in making this imputation is illustrated by the case of People v. Thomas, 25 Cal. 2d 880, 889-900, 156 P.2d 7, 12-13 (1945).

102. Jones \& Davis, Attribution Process in Person Perception, in 2 Advances IN Experimental Social Psychologx 219 (L. Berkowitz ed. 1965). 
that the man is angry (specific internal state) at the child. The man's anger may be inferred from the child's suffering immediately following the blow (an effect of the act) or from the observer's knowledge that the man is generally hostile (general internal disposition). Furthermore, where the man's anger is perceived as being caused by the child's behavior (an external source), the man will be held less responsible for any harmful effect to the child than if his anger were perceived to stem from his general hostility.

An observer may infer the actor's internal state (e.g., anger) at the time of the act "down" from what the observer perceives to be the actor's general internal disposition (e.g., hostility), or the observer may infer the crucial internal state of the actor at the time of the act "up" from the effect of the act (e.g., the child's crying), seeking correspondence ${ }^{103}$ between the consequences of the act and the actor's internal state. For example, if our unfortunate child is frail and dies from the man's blow, the man's internal state will be perceived by an observer as more culpable-due to more anger or greater intention to cause serious harm-than if the child suffered only a bruise, no matter what the man's internal state actually was, and more responsibility for the act will be attributed to him.

The process of attributing internal states to an actor is an important determinant of the observer's perception of the actor's responsibility for an event. Such internal states become relevant inputs in the juror's sense of equity.

\section{Applications of Equity and Attribution Theory}

\section{A. Suggested Principles of Jury Equity}

The real importance of the theory and research findings of social psychologists interested in equitable behavior and attribution of responsibility lies in the framework they provide for systematically pur-

103. Jones \& Davis, supra note 102, use the term "correspondence" to describe the association which people tend to perceive between an actor's internal state and the effect of the act or between the actor's internal state and the actor's general disposition.

The correspondence observers seek between an actor's internal state and the effects of an act is illustrated by an experiment by Walster, who found that the more severe were the negative consequences of an act, the more an observer held the actor responsible for the act. Subjects listened to tape recordings of four versions of an account of a man whose car accidentally rolled down a hill. The accounts were identical except for the consequences of the accident, which ranged from little to severe damage and injury to others. The results show that subjects imputed a more culpable internal state to the man as the severity of the consequences of the accident increased. Walster, Assignment of Responsibility for an Accident, 3 J. PERs. \& Soc. PSYCH. 73 (1966). 
suing answers to questions about the jury's sense of equity. Without the direction provided by such a theoretical framework, lawyers would be left to guess the "principles" of jury equity from empirical generalizations such as those reported by Kalven and Zeisel ${ }^{104}$ or, worse, from the educated guesses and folk wisdom of experienced trial lawyers. As research on equitable behavior and the attribution of responsibility continues, further dimensions of the juror's sense of equity will be uncovered. ${ }^{105}$ Although the purpose of this Note is chiefly to point out the direction that social psychology can provide to legal researchers interested in jury sovereignty and jury equity, selected preliminary principles of jury equity based on existing social psychological research findings can be formulated for purposes of illustration. ${ }^{106}$

104. H. KALVEN \& H. ZEISEL, supra note 13.

105. To the extent that perceptions of fairness or equity differ among individuals in a given community, social psychologists are interested in learning how to predict such differences. Experimental research indicates that certain personality characteristics can explain much of the variation in individual perceptions of equity. See Legant, supra note $60 ;$ cf. note 50 supra.

For example, high authoritarians have been found to attribute responsibility to an accused against whom there is little or ambiguous evidence more often than do low authoritarians. P. Legant, The Deserving Victim: Effects of Length of Pretrial Detention, Crime Severity, and Juror Attitudes on Simulated Jury Decisions (unpublished doctoral dissertation, Yale University 1973); Boehm, Mr. Prejudice, Miss Sympathy, and the Authoritarian Personality: An Application of Psychological Measuring Techniques to the Problem of Jury Bias, 1968 WIs. L. REv. 734 (1968); Crosson, An Investigation into Certain Personality Variables Among Capital Trial Jurors, 3 ProCeedings, 76th Annual Convention, Am. Psych. Ass'N 371 (1968); Jurow, New Data on the Effect of a "Death Qualified" Jury on the Guilt Determination Process, 84 HaRv. L. REv. 567 (1971); Mitchell \& Byrne, Minimizing the Influence of Irrelevant Factors in the Courtroom: The Defendant's Character, Judge's Instructions, and Altthoritarianism (unpublished manuscript, Purdue University 1972); Sulzer \& Burglass, supra note 88. Legant, for example, found that even though all her experimental jurors had viewed the same video-taped simulated trial, those jurors who scored high on a measure of authoritarianism liked the defendant significantly less and suggested a significantly longer sentence for him than did jurors who had low scores on the authoritarianism measure. P. Legant, supra. In addition, Sulzer and Burglass found that as the ambiguity of an actor's responsibility for harm done increased (while the severity of harm done remained constant), the discrepancy in responsibility for the harm attributed to him by high and low authoritarian subjects also increased, the high authoritarians attributing relatively more responsibility to the actor than the low authoritarians. Sulzer \& Burglass, supra note 88.

By way of comparison, Goldstein, the noted trial tactician, recommends that plain. tiff's counsel should seek jurors of Irish, Jewish, Italian, French, and Slavic national origin because these nationalities are less strict than the Nordic type of juror (German, English, and Scandinavian) and will more readily sympathize with the plaintiff. I. Goldstein, supra note 29, at 156-57. See also H. RothblatT, Successful Techniques in the Trial of Criminal Cases (1961). If the so-called Nordic juror, however, tends to be more authoritarian than other jurors, as commonly thought, the research just described indicates that Nordic jurors would in fact be more plaintiff-oriented than other jurors in a close case where defendant's responsibility for the resulting harm is ambiguous.

106. Empirical testing of these or other suggested principles of jury equity of course requires that techniques be developed for operationalizing the principles and concepts contained therein in experimental judicial settings. See note 148 infra.

It should be made clear that these preliminary principles of jury equity are not 
Principle One. The more the defendant incurs "costs" in the commission of an offense, the less punishment he will be given.

If the defendant has been injured or suffers other costs in connection with his "inequitable relationship" with his victim, he reduces his outcomes from the relationship and thus less punishment should be required to restore equity to the relationship. ${ }^{107}$ Kalven and Zeisel ${ }^{108}$ report that several juries they studied gave light sentences to defendants who received considerable "punishment" from the commission of the crime itself. ${ }^{109}$

Similar considerations of inadvertently reduced inequity are reported in experiments by Bramel ${ }^{110}$ and Berscheid, ${ }^{111}$ who found that fortuitous punishment of an offender reduced the victim's need to personally restore equity. Walster ${ }^{112}$ cautions, however, that fortuitous punishment will reduce inequity only where there is a causal relationship between the offense and the defendant's suffering ${ }^{113}$ (as would most certainly be the case where defendant is injured in the commission of the offense). Legant's ${ }^{114}$ experimental finding that sentences handed down by simulated jurors did not reflect the length of time defendant had spent in pretrial detention indicates that even such pre-

presented as normative propositions for legal reform. They are merely descriptive of dimensions of jury equity which seem to be indicated by social psychological research. Whether they should be incorporated into the legal system or whether juries should be instructed against following them is a separate question not addressed here.

107. Since equity may also be restored by changing one's perceptions of the relevant inputs of the participants, however, this hypothesis is open to the criticism that the defendant's suffering could make the defendant less attractive and thus become a negative input rather than a negative outcome in the equity equation. This would actually increase the inequity between the defendant and his victim. See Lerner, supra note 70. Further research is needed to determine when the defendant's suffering will elicit actual as opposed to psychological compensation.

108. H. KALven \& H. ZeIsel, supra note 13, at 301-05.

109. Judges have also reasoned this way. In a case in New Haven Superior Court, Judge O'Sullivan, in lieu of a jail term or even probation, was content to levy a $\$ 100$ fine on a defendant with a lengthy criminal record who was found guilty of assault for threatening his former wife with a knife. Commenting on the fact that the defendant had been shot by his former wife during the commission of the offense, losing a kidney as a result, Judge O'Sullivan said, "He's been punished more than anything I could do." New Haven Register, April 7, 1973, at 42, col. 7; see also id., March 17, 1973, at 42 , col. 1 .

110. Bramel, Taub \& Blum, An Observer's Reaction to the Suffering of His Enemy, 8 J. Pers. \& Soc. Psych. 384 (1968).

111. Berscheid, Boye \& Walster, Retaliation as a Means of Restoring Equity, 10 J. Pers. \& Soc. Psych. 370 (1968).

112. E. Walster, Equity Theory (unpublished manuscript 1973).

113. Compare this required nexus to the principle of legal equity that "he who seeks equity must do equity," H. McClintock, supra note 1 , at 55 , and the limitation on this principle that "a party can be required to do equity only with respect to the transaction as to which he seeks equitable relief." Id. at 57.

114. P. Legant, supra note 105. 
trial detention may be outside of the required causal relationship between the offense and the inadvertent punishment. ${ }^{115}$

Principle Two. Diminished capacity of the defendant at the time of the offense will be a successful defense the more the defendant's behavior was "out of character" for him while his capacity was diminished.

The Model Penal Code ${ }^{116}$ proposes that one mitigating circumstance in a murder conviction is that: "At the time of the murder, the capacity of the defendant to appreciate the criminality (wrongfulness) of his conduct or to conform his conduct to the requirements of law was impaired as a result of mental disease or defect or intoxication." While at least one judge feels that the defense of intoxication does not generally appeal to the jury, ${ }^{117}$ Kalven and Zeisel conclude from their study that the jury may attribute responsibility for the crime to alcohol rather than to the defendant if the defendant's actions were "utterly out of character for him,"118 thus exculpating the harmdoer in an inequitable relationship.

Social psychologists provide theoretical and experimental support for Kalven and Zeisel's conclusion about this aspect of jury equity. Jones and Nisbett ${ }^{119}$ and Nisbett and associates ${ }^{120}$ have demonstrated that actors tend to attribute their behavior to environmental causes (such as intoxication), while observers usually attribute the causes of behavior to an actor's personal traits. Reisman and Schopler, ${ }^{121}$ however, have demonstrated that when behavior is not characteristic of an actor's past behavior or general dispositional traits, responsibility for the behavior is attributed to environmental causes rather than to the actor. For instance, suppose a normally mild-mannered person becomes angry and strikes the person who has roused his anger. Reisman and Schopler's research indicates that observers of such behavior will attribute the actor's behavior to "anger" and assign relatively little responsibility to the generally mild-mannered actor; the emo-

115. For isolated examples of defendants who did receive lighter sentences after long periods of pretrial detention, however, see H. KALvEN \& H. ZEISEL, supra note 13, at 303-05.

116. See Model Penal Code $\$ 210.6(4)(\mathrm{g})$ (Proposed Official Draft 1962) and Comment at 68-74 (Tent. Draft No. 9, 1959). See also notes 94-95 supra.

117. H. KALVEN \& H. ZEISEL, supra note 13 , at 335 .

118. Cf. Springfield v. State, 96 Ala. 81, 11 So. 250 (1892) (requested instruction concerning the exculpatory effect of the combination of defendant's good character and his intoxication at the time of the offense disallowed).

119. Jones \& Nisbett, supra note 79.

120. Nisbett, Caputo, Legant \& Marecek, supra note 79.

121. Reisman \& Schopler, An Analysis of the Attribution Process and an Application to Determinants of Responsibility, 25 J. Pers. \& Soc. PsYch. 361 (1973). 
tional state of "anger" is not closely associated with the actor in this instance and thus becomes a separate, external cause of the actor's behavior. This example is similar to a defendant who commits a crime under diminished capacity. If the crime is not characteristic of the defendant, an observer will tend to attribute the cause of the crime to the source of the diminished capacity rather than to the defendant.

Principle Three. The greater the ambiguity surrounding the defendant's civil liability or criminal guilt, the milder the damages or punishment will be.

This principle illustrates one way in which notions of equity may take into account variables affecting attribution of responsibility for the inequitable event. Given two similar events where the plaintiff or victim suffers equally severe harm at the hands of similar defendants found liable for the harm done or guilty of the crime, the equity equation as well as the legal system would seem to demand equal damages or punishment to restore equity. Research on the attribution of responsibility, however, indicates that where it has such discretion ${ }^{122}$ the jury will return a harsher verdict against that defendant against whom there is more evidence of liability or guilt, in effect discounting the inequity by the degree of uncertainty of the evidence concerning the defendant's responsibility for the inequitable event. ${ }^{\mathbf{1 2 3}}$

The Model Penal Code and Proposed Federal Criminal Code reflect this principle of jury equity. In sentencing a defendant who has been found guilty of murder, both Codes would preclude the death penalty from being imposed in cases where the court determines that "although the evidence suffices to sustain the verdict, it does not foreclose all doubt respecting the defendant's guilt." ${ }^{124}$ In addition, Kalven

122. In addition to recommending sentence and assessing damages, a jury may have the right to determine the grade of the offense of which the defendant is to be convicted. See Allison v. State, 74 Ark. 444, 86 S.W. 409 (1905); Model Penal Code $\$$ 2.02(10) (Proposed Official Draft 1962) and Comment at 131-32 (Tent. Draft No. 4, 1955).

123. The threshold problem of the minimum level of evidence necessary to find the defendant liable or guilty in the first place is of course different in civil than in criminal cases. A civil case in favor of the plaintiff decided under the "preponderance of evidence" standard of certainty can legitimately leave some degree of doubt in the mind of the juror as to the defendant's actual culpability. In contrast, the uncertainty which a juror in a criminal case can feel about the defendant's actual guilt and yet still convict under the stricter "beyond a reasonable doubt" standard is problematic. Although reasonable doubt surely does not mean not any doubt, cf. MODEL PENal Code, supra note 97, and note 127 infra, the impact of Principle Three may be more pronounced in civil rather than in criminal cases becausc of the extremely high level of certainty ideally required for a criminal conviction.

124. Model Penal Code $\$ 201.6(\mathrm{l})(\mathrm{g})$ (Proposed Official Draft 1962); Proposed Federal Criminal Code, Provisional $\$ 3603$ (c) (Final Report, National Commission on Reform of Federal Criminal Laws, 1971). 
found in a study using experimental civil juries that where the amount of harm done by the defendant was held constant, the experimental juries awarded less in damages as the liability of the defendant became less clear. ${ }^{125}$

Social psychologists have also found experimental support for this principle. Phares and Wilson, for example, offer evidence that where the severity of the consequences is held constant, simulated jurors exact less compensation from defendants the more the defendants are not "wholly guilty." 126 Eighty subjects were presented with summaries of eight actual civil cases, won by the plaintiff, which varied in severity of the harm done (from severe to mild) and certainty of defendant's liability (from certain to ambiguous). The subjects were asked to assess the cases themselves and make an award of damages. Within each category of severity of harm done, significantly higher damages were awarded in the cases where defendant's liability was certain rather than ambiguous. This indicates that jury equity takes into account any doubt the jurors have about the defendant's liability or guilt in its assessment of damages or punishment. ${ }^{127}$

Principle Four. The less attractive the defendant or the more attractive the victim, the more punishment the defendant will be given for injuring the victim.

This principle is based on the notion that attractiveness-good character, high social status, good looks, pleasing personality-is an asset in the equity equation, entitling a participant in a relationship to relatively more rewards than an unattractive person. Thus, the less attractive the defendant or more attractive the defendant's victim, the more inequitable is the defendant's relationship with his victim, demanding more punishment or a higher damage award to restore equity.

There is widespread support for this principle. At least one trial tactician urges defense counsel to emphasize the unpleasantness of the victim in attempting to mitigate the defendant's offense. ${ }^{128}$ Also, Kalven and Zeisel ${ }^{129}$ report that in cases they studied where the jury

125. Kalven, supra note 33 .

126. Phares \& Wilson, Responsibility Attribution: Role of Outcome Severity, Situational Ambiguity, and Internal-External Control, 40 J. PERs. 392 (1972).

127. Compare Judge Frankel's intimation that it might not be improper for the sentencing judge to take into account the weight of the evidence regarding defendant's guilt in passing sentence. Frankel, Lawlessness in Sentencing, $41 \mathrm{U}$. CINN. L. REV. 1, 25-26 (1972).

128. Cohen, Trial Tactics in Criminal Cases, in Legal and Crintinal Psxchology 51, 67-68 (H. Toch. ed. 1961).

129. H. KaLven \& H. ZEISEL, supra note 13, at 200-18. 
acquitted a defendant whom the judge would have convicted, a frequent cause of the jury's leniency was an attractive characteristic of the defendant. ${ }^{130}$

In addition, the principle is consistently supported in research by equity theorists. For example, Landy and Aronson ${ }^{131}$ conducted two $^{2}$ experiments in which subjects read a description of a negligent homicide case and were instructed to sentence the defendant to a term of years in prison as if they were a juror in the case. The accounts of the case read by the subjects were identical, except that in the first experiment the victim was described as an unattractive person to half the subjects and as an attractive person to the other half. ${ }^{132}$ The second experiment was similar to the first, except that the attractiveness of the defendant was also varied. The results were as expected: Subjects presented with an attractive victim sentenced the defendant more severely than did subjects presented with an unattractive victim, while the attractive defendant was sentenced less severely than the unattractive defendant. These results suggest that a defendant planning to use the "sad tale account" described by Scott and Lyman to evoke the jury's sympathy runs the risk of making himself unattractive to the jury in the process. ${ }^{133}$

Principle Five. The more the jury perceives that the defendant is being singled out for prosecution from among others who are also guilty of the same or a similar offense, the less punishment the defendant will be given.

This occurs where the jury learns that an accomplice of the defendant is not being prosecuted or is receiving preferential treatment, per-

130. Kalven and Zeisel also predict on the basis of their data that an unattractive defendant would have a converse effect on the jury. Id. at 217.

131. Landy \& Aronson, The Influence of the Character of the Criminal and His Iiclim on the Decisions of Simulated Jurors, 5 J. ExP. Soc. PsYch. 141 (1969). See also Mitchell \& Byrne, supra note 105; Jones \& Aronson, Attribution of Fault to a Rape Victim as a Function of Responsibility of the Victim, 26 J. PERs. \& Soc. PsYch. 415 (1973); Lerner, Evalualion of Performance as a Function of Performer's Reward and Altractiveness, 1 J. Pers. \& Soc. P'SYch. 355 (1965); Mitchell \& Byrne, The Defendant's Dilemma: Effects of Jurors' Attitudes and Authoritarianism on Judicial Decisions, 25 J. PERs. \& Soc. I'srCh. 123 (1973); Sigall \& Landy, Effects of the Defendant's Character and Suffering on Juridic Judgment: $A$ Replication and Clarification, $88 \mathrm{~J}$. Soc. Psycir. 149 (1972).

132. The attractive victim was a stock broker, active in the community, and a widower, who at the time of the mishap was on his way to an orphanage with Cliristmas gifts. The unattractive victim was described as a notorious hoodlum and cx-convict, a member of a crime syndicate which the police were investigating, who was carrying a loaded 32-caliber pistol at the time of the mishap. The attractive and unattractive defendants were similarly described. Landy \& Aronson, supra note 131,
at 145,148 .

133. Scott \& Lyman, supra note 87, at 52. 
haps having "copped a plea." Kalven and Zeisel ${ }^{134}$ report cases where juries acquitted a defendant, though the judge would have convicted him, because the jury learned that the prosecution had charged an accomplice with a lesser offense or had not prosecuted the accomplice at all. ${ }^{135}$ In a study of prison inmates, Casper ${ }^{136}$ found that inmates were not so much concerned about lengthy sentences or the basic equity of their own sentences as they were with how the severity of their own sentence compared with that of other offenders found guilty of a similar crime.

This principle also applies where the defendant is being prosecuted for breaking a law which is seldom enforced or is broken with impunity by others. Kalven and Zeisel ${ }^{137}$ again report that their findings indicate that the jury is often unwilling to convict for a violation of "sumptuary legislation" concerning, for example, gambling and intoxication, because of the jury's perception that widespread violation of these laws is tolerated. ${ }^{138}$ In addition, Scott and Lyman insist that the justification of "condemning the condemners"-arguing that others frequently commit the impropriety which one is accused of without being punished-is a common means of "accounting" for one's untoward behavior in everyday life. ${ }^{139}$

An explanation of this principle based on equity theory might be that where the jury believes that the defendant is being singled out for prosecution, the defendant's ratio of outcomes to inputs is less frequently compared with his victim's ratio than it is with the outcomes and inputs of accomplices in the same offense or of others who regularly violate the law without cost. The jury works equity between similar offenders as well as between offender and victim. This equity principle of "even-handed justice" has not yet been explored in social psychological investigations.

\section{B. Effectiveness of Jury Instructions}

No principle has been formulated concerning factors which influence the effectiveness of the judge's legal instructions in convincing

134. H. KALVEN \& H. ZeIsel, supra note 13, at 313-17.

135. Viewing the prosecution as plaintiff in a suit in equity, compare the principle of legal equity that "he who seeks equity must do equity." H. McClintock, supra note 1 , at 55 .

136. J. Casper, American Criminal Justice: The Defendant's Perspective 89 (1971).

137. H. KALVEN \& H. ZeISEL, supra note 13 , at 287.

138. Viewing the prosecutor as representing a community which often breaks the law for which the defendant is being prosecuted, compare the principle of legal equity that one must "come into equity with clean hands." H. ḾcClintock, supra note 1 , at 59 .

139. Scott \& Lyman, supra note 87 , at 51 . 
the jury to rely on legally relevant criteria as opposed to its own sense of equity in reaching its verdict. ${ }^{140}$ Critics of jury sovereignty maintain that the juror has a mind of his own and that legal instructions have little if any predictable effect on quelling the so-called irrational factors which affect his decisionmaking. ${ }^{141}$ Social psychological research, however, has repeatedly shown that differential instructions to experimental subjects can produce significantly different attitudes and behavior ${ }^{142}$ and that subjects are usually quite willing to put their complete trust in an experimenter's judgment about what constitutes proper and improper behavior.

The extent to which subjects are willing to follow the instructions of the experimenter was demonstrated dramatically in an experiment by Milgram, ${ }^{143}$ who succeeded in persuading his subjects to administer what the subjects thought were near fatal electric shocks to a fellow student simply by instructing them to do so. Under the guise of conducting research on the effect of punishment on memory, Milgram instructed individual subjects to administer increasingly severe shocks to an accomplice of the experimenter each time the accomplice gave a wrong answer to a series of questions. As the shocks increased to near fatal dosages and the accomplice's cries of anguish increased, many subjects attempted to break off the experiment. Milgram instructed them to continue, however, and a remarkable 62 percent of all subjects, complying with Milgram's instructions, did continue and administered what they thought to be the maximum, near fatal shock. Milgram thus successfully instructed his subjects to suspend their own personal senses of propriety for the duration of the experimental session. A judge may be likened to an experimenter as a strong authority figure who instructs jurors on the requirements of their roles as jurors. If the experimenter can successfully instruct his subjects by means available to the judge that the subject's own sense of fairness or equity is not relevant to his role as subject, then the judge should likewise

140. Inasmuch as the judge's instructions constitute an attempt to persuade the jury not to follow its own sense of equity but to follow instead the results indicated by applicable law, the research on persuasive communications should help isolate factors which will affect the judge's persuasiveness. See, e.g., C. Hovland, I. Janis, \& H. Kelley, Communication \& Persuasion (1953). For a good review of such research applied to the courtroom, see Commentary, supra note 27.

141. See pp. 1026-28 \& note 26 supra.

142. See Aderman \& Berkowitz, Observational Set, Empathy, and Helping, $14 \mathrm{~J}$. PERS. \& Soc. PSYCH. 141 (1970); Stotland, Exploratory Investigations of Empathy, in 4 Advances in Experimental Social Psxchology 271 (L. Berkowitz ed. 1969).

143. Milgram, Some Conditions of Obedience and Disobedience to Authority, 18 HuMAN REL. 57 (1965). Milgram's experiments were conducted both at Yale University and in Bridgeport, Connecticut. 
be able to persuade jurors that their own personal senses of equity are not relevant to their roles as jurors. ${ }^{144}$

Little research has been done on the amount of influence the judge exerts through his instructions on the juror's performance of his role as juror. Simon found that different judicial instructions to the jury on the defense of insanity led to a significant difference in the frequency of a finding of insanity by the jury, ${ }^{14 \tilde{s}}$ and Mitchell and Byrne report experimental evidence that low authoritarian simulated jurors are much more responsive to judicial instructions than are high authoritarians. ${ }^{146}$

More research is obviously needed on the impact of judicial instructions on juror decisionmaking and on what factors influence that impact, especially in light of the inconsistent findings of existing studies. ${ }^{147}$

\section{G. Implications for Legal Issues}

The above principles, and the more general hypotheses of social psychology's equity and attribution theories from which they are derived, suggest that members of a community internalize commonly held notions of equitable relationships. Also, as jurors observing inequitable relationships, they are psychologically motivated to act according to those shared notions in reaching a verdict and apportioning rewards and punishments. The theory itself, and the refined empirical data for which it calls, ${ }^{148}$ can have important implications

144. Admittedly, Milgram had the advantage of continuous eye contact and close proximity to his subjects (compliance decreased as Milgram stood further from the stbjects), and he was able constantly to urge the subjects to proceed at every sign of hesitation. These compliance strategies are generally not available to a judge. On the other hand, the jury neither witnesses the victim's actual suffering nor must it personally inflict compensation or punishment on the defendant, both factors which encourage reliance on personal rather than on legal criteria of justice. In addition, in experiments much less drastic than Milgram's, differential written instructions significantly altered subjects' responses to the imagined suffering of another. See note 142 supra. This indicates that a judge need not go to the lengths Milgram did before his instructions will have a significant impact on the jury.

145. R. Simon, supra note 49.

146. Mitchell \& Byrne, supra note 105.

147. Evidence that jurors do follow judicial instructions: $R$. Simon, supra note 49; Mitchell \& Byrne, supra note 105; Kalven, supra note 25, at 1064-65.

Evidence that judicial instructions can influence jurors: Aderman \& Berkowitz, supra note 142; Milgram, supra note 143; Stotland, supra note 142.

Evidence that jurors do not follow judicial instructions: Broeder, supra note 26; Hervey, supra note 18; Hoffman \&: Brodley, supra note 18; Hunter, supra note 18 .

148. Investigations on the impact of the jury's sense of equity on jury decisionmaking are hampered by the fact that actual juries are inaccessible to researchers. Alternatives to studying real-life juries as they reach their verdict, therefore, have had to be developed. One such alternative is the survey method used by H. KaLvEN \& H. ZeIsel, supra note 13. Data on over 3,500 actual cases accumulated through questionnaires sent to presiding trial judges were used to make comparisons between the jury's actual decision and how the judge indicated he would have decided the case.

In contrast, the experimental method allows much greater control than the survey 
for many issues in the debate concerning the role of jury sovereignty.

One important question, for example, is whether the judge should instruct the jury about its power of nullification in a criminal case. In United States $v$. Dougherty, ${ }^{149}$ the defendant's request for such an instruction was denied, Judge Leventhal fearing unjust acquittals ${ }^{150}$ and a loss of the tension in the juror's role between following general law as opposed to the juror's own sense of justice. ${ }^{151}$ Chief Judge Bazelon, dissenting in part, ${ }^{152}$ argued that the jury should be informed of its function as the conscience of the community in the particular case $^{1 \bar{v} 3}$ and felt that internal checks would restrain the jury's willingness to acquit. ${ }^{15 t}$ Social psychological research indicates that the internal checks referred to by Chief Judge Bazelon are very real and that, even where he knows of his power of nullification, a juror has a strong psychological need to see the case settled according to his sense of equity. ${ }^{1 \tilde{s}}$ This need should act as a restraint on the juror's feelings of sympathy for the defendant. In light of a judge's probable influence

method over the suspected determinants of jury decisionmaking which the investigator wishes to explore. One drawback of the experimental method is that it requires the investigator to rely on data from simulated trial settings and then apply the data from such settings to an actual trial jury. Making valid generalizations from simulated trial settings depends heavily on the investigator's ability to recreate the essential dynamics of an actual trial and researchers have sought to simulate these dynamics in various ways. Mitchell \& Byrne, supra note 105 , had student subjects read a summarized transcript of an actual criminal trial and indicate their certainty of the defendant's guilt and the amount of punishment he should receive. Thibaut, Walker \&: Lind, Adversary Presentation and Bias in Legal Decision Making, 86 HARv. L. Rev. 386 (1972), and Walker, Thibaut \& Andreoli, Order of Presentation at Trials, 82 YALE L.J. 216 (1972), had experimental assistants, representing prosecution and defense attorneys, read the facts of a simulated case to student subjects who then rendered a verdict. R. Sinion, supra note 49 , presented her subjects, who were drawn from local jury pools and ordered to participate in the experiment by a local judge, with a 60 to 90 minute tape-recording recreating an actual trial. The subjects rendered an individual and a group verdict and reported the group verdict to the judge, who had stressed to them the importance of their participation in the experiment. $P$. Legant, supra note 105, modified Simon's procedure by using a video-tape recording and conducting the simulated trial sessions in a law school courtroom. See also Legant, supra note 60 , at $33-35$.

Perhaps the most significant defect in all of these simulations of an actual trial is the fact that the simulated jurors know that their verdict does not have any consequence for an actual defendant. Perhaps the best that can be done, short of hoaxing subjects into believing that their verdict will have some real effect on the case they are deciding, is to emphasize to simulated jurors the importance of their performance, stressing its effect on future reforms of the trial process. The extent of the contribution social psychologists can make to an understanding of jury behavior and trial dynamics will depend in great part on their success in recreating the judicial setting and on the generalizability of their research findings.

149. 473 F.2d 1113 (D.C. Cir. 1972).

150. Id. at 1135-36.

151. Id. at 1136-37. See also Kadish \& Kadish, supra note 38.

152. 473 F.2d at $1138-44$.

153. Id. at 1140 n.5, 1141. See also United States v. Eichberg, 439 F.2d 620, 623-25 (D.C. Cir. 1971) (Bazelon, C.J., concurring).

154. 473 F.2d at 1143 .

155. See $\$$ II.B \& note 55 supra. 
as an authority figure on the way the jurors perceive their own roles, ${ }^{150}$ an instruction which informed the jury of its power of nullification but at the same time conveyed the legal system's expectation that it follow the general law in reaching its verdict would likely retain the necessary tension in the jury's role. ${ }^{15 \pi}$

A second question concerns a jury's erstwhile discretion to impose the death penalty. In Furman v. Georgia ${ }^{158}$ five Justices found that the death penalty was cruel and unusual because, among other things, its application was likely the result of racial discrimination; ${ }^{150}$ it was imposed by juries operating without legislative standards; ${ }^{100}$ and it was, like lightning, arbitrary in striking a target. ${ }^{101}$ While the model suggested by this Note cannot answer the ultimate question of Eighth Amendment violation, ${ }^{162}$ it does have a bearing on some of the types of questions the Court might ask in reaching its decision.

Social psychological research suggests that jurors are highly motivated to apply shared notions of equity in evaluating the seriousness of an offense and in deciding whether the death penalty is appropriate in the particular case. ${ }^{163}$ It is at odds with the lightning metaphor of Justice Stewart, ${ }^{16-4}$ hypothesizing instead that the jury has reacted in accord with shared community values. ${ }^{165}$ The fact that the Court, at a later time, without the benefit of direct observation of the trial and without going through the same decisionmaking process as a jury,

\footnotetext{
156. See § III.B supra.

157. See pp. 1029-30 \& note 38 supra.

158. 408 U.S. 238 (1972).

159. Id. at 364-65 (Marshall, J., concurring); cf. id. at 249-53 (Douglas, J., concurring).

160. See, e.g., id. at 253 (Douglas, J., concurring); id. at 295 (Brennan, J., concurring).

161. "These death sentences are cruel and unusual in the same way that being struck by lightning is cruel and unusual." Id. at 309 (Stewart, J., concurring). The Justices do not necessarily confine their major criticisms to the arbitrariness of juries. Justice Brennan, for example, discussed data relating to postjury-verdict executions as compared with commutations and resentences. $I d$. at 292-93.

162. Aside from the arguments reviewed in this section, the validity of the death penalty might be evaluated differently on the basis of its character as a punishment, cf. id. at 269-74 (Brennan, J., concurring), or its relationship to other legitimate ends of the state, see, e.g., id. at $342 \cdot 59$ (Marshall, J., concurring).

163. Chief Justice Burger points out that the majority is willing to accept this relationship between jury verdicts and community values, but only when the jury has not imposed the death penalty. Id. at 387. See, e.g., id. at 279, 286 (Brennan, $\mathrm{J}$, concurring). At other times, infrequency of such a punishment is used to infer arbitrariness. See, e.g., id. at 249 (Douglas, J., concurring).

164. See note 161 supra.

165. See note 163 supra. Justice White, concurring in the decision, determined that:

The short of it is that the policy of vesting sentencing authority primarily in juries-a decision largely motivated by the desire to mitigate the harshness of the law and to bring community judgment to bear on the sentence as well as guilt or innocence-has so effectively achieved its aims that capital punishment within the confines of the statutes now before us has for all practical purposes run its course.

408 U.S. at 313 (emphasis added).
} 
cannot always see the relationship between the penalty imposed and community justice should not be very surprising. But these are all important elements in knowing whether the jury does in fact, as Justice Stewart and others suggest, act arbitrarily.

There is the further question, however, whether and to what extent certain of these shared notions, for example attractiveness, ${ }^{166}$ hinge on legally impermissible considerations, for example race. But inquiry need not necessarily end there. If such elements are determinative or substantially influential-albeit subconsciously-for individuals who can be segregated through study of their shared notions with identifiable subclasses, ${ }^{167}$ perhaps the problem can be eliminated during the jury selection process. If legally impermissible considerations weigh on the minds of otherwise acceptable and nonsegregatable jurors, there is a further question to what extent, if at all, the considerations may be overcome by appropriate judicial warning and instruction. ${ }^{168}$

The answers to the above questions would provide a greater step toward solving the problem than deciding death penalty cases on the basis of the existence of legislative standards. ${ }^{109}$ Equity theory hypothesizes that the jury's shared notions of equity in such cases are the very notions which a legislature would rely on in working out useful guidelines for imposing the death penalty. ${ }^{170}$ The inference, that the decision of a jury having no legislative standards to "guide" it is arbitrary, ${ }^{171}$ or, conversely, that a jury having the benefits of legislative standards will necessarily suppress all power of discretion, will likely be proven invalid. Thus legislative standards for imposing capital pun-

166. See pp. 1046-47 supra.

167. See note 105 supra.

168. See $\$$ III.B supra. The basic question, therefore, e.g., in the case of racial prejudice of jurors, is whether such prejudice simply calls for more stringent procedures or is inherently incapable of solution; cf. 408 U.S. at 242 (Douglas, J., concurring); id. at 295 (Brennan, J., concurring). The issue, of course, is further complicated to the extent that the problem is also one of pretrial selection for prosecution and post-trial commutations, etc. See note 161 supra. This discussion is concerned solely with jury roles and not with all aspects of the death penalty controversy as such.

169. The exact standards are not mentioned in the opinions, but seem to be those discussed in McGautha v. California, 402 U.S. 183 (1971). See, e.g., 408 U.S. at 247 (Douglas, J., concurring). In McGautha, the Court, upholding the right of a state to rely on jury discretion rather than itself trying to set down specific standards, referred to those factors discussed in the Model Penal Code and the Proposed Federal Criminal Code of the Commission on Reform of Federal Criminal Laws. 402 U.S. at 205.08. The Model Code and the Commission's Final Report are discussed at p. 1045 supra; see also a suggestion for a "sentencing calculus" in Frankel, supra note 127, at $41-48$.

170. See Furman v. Georgia, 408 U.S. at 313 (White, J., concurring); id. at 388-89 (Burger, C.J., dissenting); MCGautha v. California, 402 U.S. 183, 205.08 (1971). See generally § II supra.

171. See, e.g., Furman v. Georgia, 408 U.S. at 295 (Brennan, J., concurring). 
ishment are a dubious improvement, as Justice Harlan noted in McGautha $v$. California, ${ }^{172}$ since in such a serious matter they may be resisted by juries where they significantly deviated from the jury's own sense of justice. ${ }^{173}$

Out of a desire to severely restrict possible imposition of the death penalty, the Court might mean, when referring to "legislative standards," mandatory sentencing statutes for certain classes of acts. ${ }^{174}$ But even when faced with such statutes, a jury can exercise its sense of equity by the finding or not of guilt.. ${ }^{175}$ This realization again raises the earlier question whether the jury ought not, in such circumstances, be instructed as to its powers of nullification. ${ }^{176}$

\section{Conclusion}

Protecting jury sovereignty may be the legal system's answer to the dilemma posed by often conflicting societal demands for general rules of law as well as justice in the particular case. Social psychological theories of equity and attribution of responsibility together suggest relatively stable dimensions of the jury's commonly held sense of equity and offer a research model for a more refined study of jury behavior. The empirical data collected on the basis of this model can provide policymakers with more reliable information and a coherent frame of reference with which to decide where to expand, keep, or retract the jury's role in the legal system.

172. 402 U.S. 183, 207-08 (1971).

173. See pp. 1029-30 supra. See also note 175 infra.

174. See, e.g., Furman v. Georgia, 408 U.S. at 307-08 (Stewart, J., concurring).

175. This was recognized by both sides in Furman. See 408 U.S. at 245 n.8, 247

(Douglas, J., concurring); id. at 401 (Burger, C.J., dissenting).

176. See pp. 1050-52 supra. 